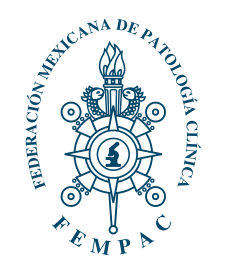

\title{
Editorial.
}

\section{Sobre la veracidad de la información}

\author{
Editorial. On the truth of the information
}

\author{
Zamora Palma Alberto*
}

$\neg$ n el mundo, existen dos maneras de tomar una decisión acertada, en el primer grupo se encuentran las personas que sin datos previos y sin confirmar la veracidad de los mismos son capaces de tomar una acción inmediata y, aun así, pueden llegar a tener certeza; en el segundo grupo se encuentran las personas que necesitan conocer la información pasada y reciente, y que se aseguran de la veracidad de la misma para tomar un criterio, en el primer grupo la probabilidad de error es mayor que en el segundo. En este sentido, nos enfrentamos a una situación compleja como la pandemia que estamos padeciendo, y es aquí donde es necesario saber los datos exactos y veraces para determinar cómo resolver un problema de manera acertada. Las interrogantes que tenemos en la actualidad y que sirven de referencia para enfrentar la propagación del virus SARS-CoV-2 son las siguientes, entre otras que pudieran surgir: ¿cuántos son los casos nuevos de personas infectadas por el virus?, ¿cuál es el número real de muertes en un periodo determinado?, ¿cuáles son los exámenes de laboratorio indicados en cada etapa clínica?, ¿cuál es el grado de confiabilidad de los mismos?, ¿cuál es la disponibilidad de camas para atender a los pacientes con enfermedad grave o crítica?, ¿cuáles son los medicamentos que en verdad son efectivos para el tratamiento de la infección en una etapa clínica determinada?, ¿por qué algunos pacientes se comportan de una manera atípica?, ¿cuáles son las mejores vacunas y cuál es el número exacto de las que se encuentran disponibles?, ¿cuánto tiempo durará el efecto protector de cada una de ellas?, ¿cuál es el valor de corte que se debe alcanzar para saber que una persona ha alcanzado el nivel de inmunidad frente al virus?, ¿por qué algunos pacientes se comportarán como respondedores generando anticuerpos y otros no? Envueltos en una maraña de datos cotidianos falsos y tendenciosos que se publican o que no se han sometido a un protocolo de investigación que genere datos duros y útiles, pasamos por un puente movedizo que facilita una dura caída en la toma de decisiones. Hoy es imprescindible caminar a pasos lentos pero seguros al generar planes de acción que nos permitan enfrentar la pandemia de COVID-19, y sólo los obtendremos a partir de la contribución responsable que aportemos el grupo de personas que seguimos el método científico estrictamente, y por este medio podremos desmentir las falsas premisas que se han generado en un mundo vertiginoso en un intento por entender la magnitud de esta terrible enfermedad.
Dr. Alberto Zamora

Palma

E-mail: albertoz100@ hotmail.com / alberto.zamora@ medigraphic.com

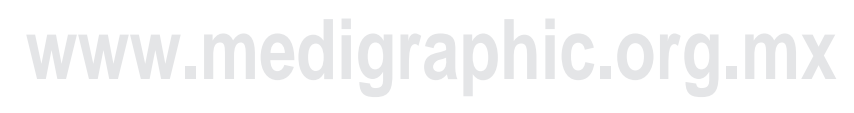

Citar como: Zamora PA. Editorial. Sobre la veracidad de la información. Rev Mex Patol Clin Med Lab. 2020; 67 (4): 172. https:// dx.doi.org/10.35366/99461 